\title{
APPLYING LINEAR PROGRAMMING APPROACH IN MODELING THE CURRENT CROP/LIVESTOCK FARMING SYSTEM IN NEW VALLEY GOVERNORATE OF EGYPT
}

\author{
M.N.M. Abd El-Ati ${ }^{1}$, Mona Mohammady I. $^{2}$, H. Hamdon ${ }^{3}$ and Doaa A. Abd El-Salam ${ }^{2}$ \\ 1-Department of Animal Production, Assiut University, 2- Animal Production and Poultry Division, Desert \\ research Center, 3- Department of Animal Production, New Valley University \\ *Corresponding author, Email: monamohammady@hotmail.com
}

Received: 9/5/2019 Accepted: 26/5/2019

\section{SUMMARY}

The present study was carried out at the New Valley governorate. Four districts were identified; El-Kharga, El-Dakhla, Baris and Balat, to identify an optimal combination among crop and livestock enterprises that would enable the smallholders meet their goals of accumulating monetary income and providing food security for the family throughout the year. Data were collected from 120 farms randomly selected represent one agricultural year (2015 - 2016). Biological and economic technical coefficients per feddan and per head of animal were estimated. Four farming plan scenarios were proposed; the first scenario (LP1) assuming free choice of cultivated crops and livestock enterprises to simulate the current status, the second scenario (LP2) assuming free choice of cultivated crops, while livestock activity was constrained by at least one head of each livestock species (cattle, sheep and goat), the third scenario (LP3) assuming that the cultivated area was distributed equally among the different crops during winter and summer seasons, and free choice of livestock activity, Finally, the fourth scenario (LP4) assuming that the cultivated area was distributed equally among the different crops, while livestock activity was constrained by at least one head of each livestock species (cattle, sheep and goat). Results showed that Balat district exceeded the current gross margin by $221 \%$, while the second scenario exceeded by $121.8 \%$ in El-dakhla district, meanwhile, the result of the third scenario revealed that El-kharga district scored the higher by $18 \%$, while no feasible solutions were obtained from LP4 in all studied districts. The current study concluded that smallholders have different goals other than just maximizing their farm GM (gross margin) to satisfy food security throughout the year for the family.

Keywords: Mixed farming system, linear programming, modeling, gross margin, New Valley, Egypt

\section{INTRODUCTION}

Farming system can be defined as a group of farms with similar structure, so that farms are likely share relatively similar production tasks (Notenbaert et al., 2009). Crop/livestock farming system, including both crop and livestock components, represents the dominant type of farms in most developing countries, and interactions among those components often have a major impact on the farming system productivity and the economic efficiency (FAO, 2009). Therefore, farmers are usually managing a wide range of interrelating components such as climate and physical environment which determine the basic nature of the farming systemitself (Rickert and Mackeon, 1991).

Usually, under such system conditions, smallholders are faced with the problem of how to allocate their limited production resources among cropping and livestock enterprises that would improve farm income. Most of the time, smallholders are using traditional method of farm planning and relying on experience and comparison with their neighbors in order to determine management decisions about what commodities to produce and in what quantities. In order to bridge allocation of available production resources problems, Majeke et al. (2013) reported that linear programming techniques can address the problem of how to select a combination of farm planning activities that is feasible, profitable and achieving food security for the family.

In Egypt, desert areas represent about $94 \%$ of the Egyptian land. About $55 \%$ of the total populations are working in agriculture sector (CAPMS, 2015). Moreover, small-scale crop/livestock farming system is the dominant system and nearly $95 \%$ of the livestock population are kept under this system (FAOSTAT 2014). In this context, the New Valley governorate, in terms of area, is considering the largest desert governorate in Egypt. Crop/livestock farming system represents the major farming system pertained in that area. The current study explores the potential of linear programming technique as a farming plan tool, therefore, the present study adopted linear programming approach to identify an optimal combination among crop and livestock enterprises in the New Valley governorate that would enable the smallholders meet their most important goals of accumulating monetary income and providing household food security throughout the year subject to a given fixed set of farm constraints.

\section{MATERIALS AND METHODS}

\section{The study area:}

The current study was carried out at the New Valley governorate. This governorate is located in the 
south western part of Egypt and lays between $25^{\circ}$; $42^{\prime}$ and $30^{\circ}$; 47' East longitude, $22^{\circ}, 30^{\prime}$ and $29^{\circ}$; 30' North latitude. The New Valley governorate is considered the largest governorate in Egypt in terms of area, which amounts to approximately 440098 $\mathrm{km}^{2}$, representing about $43.6 \%$ of the total area of Egypt. The New Valley is characterized by dry climate in summer and warm winter. Rain is a limited source of water, so that irrigation water is mainly obtained from underground water. (EEAA \& EMU, 2008 ). Four districts were identified for the current study; El-Kharga, El-Dakhla, Baris and Balat. The target districts contain a variety of small-scale mixed farming system of different farm sizes. The livelihood practices sedentary farming complement by limited livestock production. Alary et al. (2016) reported that livestock feeding resources, in these districts, are mainly based on green fodder and wheat residues in winter and green corn in summer. Detailed description of the current study area is presented in Mohammady et al. (2019).

\section{Type of data:}

Quantitative and qualitative data regarding crop and livestock enterprises were collected. Data were collected from 120 farms (30 farms from each district) randomly selected with respect that the chosen farmers practicing cultivating crops and livestock activities. The data represent one agricultural year begins from September 2015 to August 2016. Field survey, using structured questionnaire, was performed to identify available production resources. The questionnaire provided general information concerning socio-economic features, family size, age, education and their contribution in agricultural and livestock activities, farm size, herd size, main field crops and current farming practices, hired labor, veterinary services and productive performance of the farming activities. The financial data include the operational variable costs of crops and livestock enterprises and revenues generated from both.

Considerable agreement exists among research workers that development of a farming system directly depends upon an accurate inventory of available production resources through field survey of the target area. These resources provide the means of production and place an upper bound on how much production profit are possible. The recent results of field survey concerning available production resources and cropping pattern of the target districts are presented in Table (1).

Table 1. Statistics of available production resources inventory and cropping pattern in the four studied districts

\begin{tabular}{|c|c|c|c|c|}
\hline Item & Elkharga & Eldakhla & Baris & Balat \\
\hline Sample size & 30 & 30 & 30 & 30 \\
\hline Average farm size, feddan & 7.17 & 8.62 & 4.45 & 10.72 \\
\hline Average family size, member & 7.13 & 5.37 & 7.77 & 7.13 \\
\hline \multicolumn{5}{|l|}{ Livestock, head } \\
\hline Native cattle & 11.27 & 6.53 & 7.37 & 5.88 \\
\hline Sheep & 15.78 & 6.13 & 21.9 & 5.44 \\
\hline Goat & 16.85 & 7.79 & 17.17 & 3.98 \\
\hline \multicolumn{5}{|l|}{ Cropping pattern, feddan } \\
\hline \multicolumn{5}{|l|}{ Winter seas on } \\
\hline Alfalfa & 2.7 & 1.76 & 1.55 & 4.2 \\
\hline Wheat & 2.6 & 3.3 & 1.4 & 3.3 \\
\hline Bean & 0.6 & 1.25 & ---- & 0.375 \\
\hline Barley & 1.2 & 2.2 & 1.3 & 0.97 \\
\hline \multicolumn{5}{|l|}{ Summer season } \\
\hline Elephant grass & 1.2 & 0.5 & ---- & ---- \\
\hline Darawa & 1.7 & 1.5 & 1.5 & 0.16 \\
\hline W-corn & 1.2 & 1.8 & 1.2 & ---- \\
\hline Cowpeas & 1.75 & 0.6 & ---- & --- \\
\hline Fume & 0.6 & 0.12 & 1.3 & --- \\
\hline Other crops & 0.68 & 3.3 & 0.45 & 2.7 \\
\hline Aggregate cash flow, LE & 113410 & 65095 & 68391 & 59917 \\
\hline
\end{tabular}

\section{Data analysis:}

Biological technical coefficients per feddan and per head of animal of the current crop and livestock enterprises for the studied districts were estimated using fixed effects General Linear Model procedures described by SAS (2004). While economic technical coefficients (i.e. gross margin and variable costs) per feddan for each crop and per head of livestock species were derived from farm budget breakdown.
In addition, economical efficiency (GM/feddan) of the current studied farming system was calculated by dividing the whole farm gross margin by the number of units of resource needed. Obtained monetary values of model parameters are presented in Table (2). These estimates were calculated according to the pertained farm gate price of inputs and outputs during the studied agricultural year (2015-2016). 
Table 2. Model parameters estimates (LE) of crop (per feddan) and livestock (per head) enterprises of the studied districts

\begin{tabular}{lcccccccc}
\hline \multirow{2}{*}{ Variables } & \multicolumn{2}{c}{ E-Kharga } & \multicolumn{2}{c}{ E-Dakhla } & \multicolumn{2}{c}{ Baris } & \multicolumn{2}{c}{ Balat } \\
\cline { 2 - 8 } & VC & GM & VC & GM & VC & GM & VC & GM \\
\hline Winter seas on & & & & & & & & \\
$\quad$ Alfalfa & 1485 & 12983 & 1615 & 19121 & 1440 & 15136 & 1430 & 13005 \\
Wheat & 3340 & 8929 & 2162 & 2284 & 2149 & 3088 & 1880 & 3118 \\
Bean & 3037 & 6863 & 2464 & 3136 & --- & --- & 1267 & 733 \\
Barley & 1316 & 4184 & 1108 & 1674 & 1818 & 5057 & 1805 & 1926 \\
Summer season & & & & & & & & \\
Elephant grass & 1716 & 7313 & 2382 & 11618 & --- & --- & --- & -- \\
Darawa & 1054 & 1282 & 402 & 634 & 1279 & 4032 & 489 & 2636 \\
W-corn & 1088 & 1126 & 526 & 1361 & 391 & 521 & --- & --- \\
Cowpeas & 563 & 387 & 624 & 2105 & --- & --- & --- & --- \\
Fume & 1188 & 596 & 4125 & 4208 & 607 & 912 & --- & --- \\
Other crops & 3245 & 4328 & 2354 & 1857 & 3207 & 1963 & 2232 & 775 \\
Livestock & & & & & & & \\
Cattle & 5854 & 1675 & 3978 & 2299 & 3108 & 2165 & 4518 & 1570 \\
Sheep & 658 & 376 & 1083 & 967 & 690 & 147 & 1157 & 641 \\
Goat & 418 & 858 & 667 & 615 & 610 & 269 & 1056 & 690 \\
\hline VC; variable costs, GM; gross margin; GM= revenues - variable costs. & & & &
\end{tabular}

\section{Linear programming model structure:}

Mathematical programming model was constructed to resource allocation patterns that determine optimal decisions, provide the best opportunities for success in improving work and to determine which combination is the most profitable as well. The sets of parameters derived from the whole farm budget were incorporated into General Algebraic Modeling System software (GAMS, 2000) to determine the optimal solution. The current study considered land use, herd size, labor and available cash flow represent the major constrains affecting the production in the studied districts. The general mathematical formula used was as follows;

Objective function:

$$
\text { Maximize } \mathrm{Z}=\sum_{i=1}^{13} a_{i} x_{i}
$$

Where,

$\mathrm{Z}=$ total farm gross margin

$\mathrm{a}_{\mathrm{i}}=$ coefficient referring to gross margin per unit of decision variable $x_{i}$,

$\mathrm{x}_{\mathrm{i}}=$ decision variable, livestock activity; cattle (X1), sheep (X2), goat (X3), crops activity; alfalfa (X4), wheat (X5), bean (X6), barley (X7) as winter crops and elephant grass (X8), Darawa (X9), w-corn (X10), cowpeas (X11), fume (X12), other crops (X13) as summer crops.

Subject to a set of constraints expressed as inequalities:

$$
\sum_{i=j=1}^{13} C_{j} X_{i} \leq b_{i}
$$

Where:

$\mathrm{X}_{\mathrm{i}}=$ Decision variable,

$\mathrm{C}_{\mathrm{j}}=$ amount " $\mathrm{C}$ " of the resource $\mathrm{j}$ required,

$b_{i}=$ the available number of units of resource $i$.

$\mathrm{X}_{\mathrm{i}} \geq 0$
Quite often, some or all of the model parameters are subject to sources of uncertainty due to factors out of farmers' control (decline crop yield, lower milk yield and market risks). This uncertainty imposes a limit on confidence in the response and solution of the model. Therefore, in models involving many decision variables, sensitivity analysis is an essential ingredient of the model building to provide the decision makers with the minimum values of parameters incorporated in the objective function.

\section{Proposed farming plan Scenarios:}

Four farming plan scenarios were proposed with overall goals to maximize the whole farm GM and to enhance the overall economic efficiency of the current status of crop/livestock farming system. The proposed farming plan scenarios constructed the same general mathematical formula of liner programming (objective function) subject to a various set of constrains of herd size and land use, while assuming that labor and available cash flow constrains were fixed in all four proposed scenarios.

\section{Base Run Scenario (LP 1):}

The first hypothetical scenario (LP1) assuming free choice of cultivated crops and livestock enterprises to simulate the current status farming plan which considered as a base run. The objective function formula, to maximize the whole farm GM, is as mentioned before.

Subject to a set of constraints expressed as inequalities:

Herd size:

$$
\mathrm{X} 1+\mathrm{X} 2+\mathrm{X} 3=\text { average herd size }
$$

Land use:

Winter season:

$$
\mathrm{X} 4+\mathrm{X} 5+\mathrm{X} 6+\mathrm{X} 7=\text { average farm size (feddan) }
$$

Summer season: 
$\mathrm{X} 8+\mathrm{X} 9+\mathrm{X} 10+\mathrm{X} 11+\mathrm{X} 12+\mathrm{X} 13=$ average farm size (feddan)

No modifications occurred for labor and cash flow constrains.

\section{Modified herd composition scenario (LP2):}

The second hypothetical scenario (LP2) assuming free choice of cultivated crops, while livestock activity was constrained by at least one head of each livestock species (cattle, sheep and goat). The objective function formula to maximize the whole farm GM is as mentioned before.

Subject to a set of constraints expressed as inequalities:

Herd size:

$\mathrm{X} 1 \geq 1$ head of cattle

$X 2 \geq 1$ head of sheep

$\mathrm{X} 3 \geq 1$ head of goat

Land use:

Winter seas on :

$\mathrm{X} 4+\mathrm{X} 5+\mathrm{X} 6+\mathrm{X} 7=$ average farm size $($ feddan $)$ Summer season:

$\mathrm{X} 8+\mathrm{X} 9+\mathrm{X} 10+\mathrm{X} 11+\mathrm{X} 12+\mathrm{X} 13=$ average farm size (feddan)

No modifications occurred for labor and cash flow constrains.

\section{Diversity of cropping pattern Scenario (LP3):}

The third hypothetical scenario (LP3) assuming that the cultivated area was distributed equally among the different crops during winter and summer seasons, and free choice of livestock activity. The objective function formula to maximize the whole farm GM is as mentioned before.

Subject to a set of constraints expressed as inequalities:

Herd size:

Land use:

$$
\mathrm{X} 1+\mathrm{X} 2+\mathrm{X} 3=\text { average herd size }
$$

Winter season:

$\mathrm{X} 4=\mathrm{X} 5=\mathrm{X} 6=\mathrm{X} 7=1 / 4$ farm size

$\mathrm{X} 4+\mathrm{X} 5+\mathrm{X} 6+\mathrm{X} 7 \leq$ average farm size (feddan)

Summer season:

$\mathrm{X} 8=\mathrm{X} 9=\mathrm{X} 10=\mathrm{X} 11=\mathrm{X} 12=\mathrm{X} 13=1 / 6$ farm size

$\mathrm{X} 8+\mathrm{X} 9+\mathrm{X} 10+\mathrm{X} 11+\mathrm{X} 12+\mathrm{X} 13 \leq$ average farm size (feddan)

No modifications occurred for labor and cash flow constrains.

\section{Real farming plan Scenario (LP 4):}

The fourth hypothetical scenario (LP4) assuming that the cultivated area was distributed equally among the different crops, while livestock activity was constrained by at least one head of each livestock species (cattle, sheep and goat). The objective function formula to maximize the whole farm GM is as mentioned before.

Subject to a set of constraints expressed as inequalities:

Herd size:

$\mathrm{X} 1 \geq 1$ head of cattle

$\mathrm{X} 2 \geq 1$ head of sheep
$\mathrm{X} 3 \geq 1$ head of goat

Land use:

Winter season:

$\mathrm{X} 4=\mathrm{X} 5=\mathrm{X} 6=\mathrm{X} 7=1 / 4$ farm size

$\mathrm{X} 4+\mathrm{X} 5+\mathrm{X} 6+\mathrm{X} 7 \leq$ average farm size (feddan)

Summer season:

$\mathrm{X} 8=\mathrm{X} 9=\mathrm{X} 10=\mathrm{X} 11=\mathrm{X} 12=\mathrm{X} 13=1 / 6$ farm size

$\mathrm{X} 8+\mathrm{X} 9+\mathrm{X} 10+\mathrm{X} 11+\mathrm{X} 12+\mathrm{X} 13 \leq$ average farm size (feddan)

No modifications occurred for labor and cash flow constrains.

\section{RESULTS AND DISCUSSION}

\section{Expected farm gross margin:}

Optimal solutions of the proposed farming plan scenarios judging by whole farm GM criteria for assessment and crop production to fulfill home consumption required are illustrated in Figure (1). Due to variations of the GM per feddan of cropping pattern and per head of livestock in developed objective function and the set of constrains for each district, different impacts among studied districts, and even in the same district, were observed on the expected whole farm GM, as compared to the current situation.

\section{Base run scenario (LP1):}

The impact of LP1 farming plan scenario on the whole farm GM for El-Kharga, El-Dakhla, Baris and Balat districts are displayed in Figure (1). The optimal solution showed a significant positive impact on whole farm GM of all studied districts in comparison with the actual situation. The obtained whole farm gross margins were higher than those of the current situation by about $78.3 \%, 165.5 \%, 30.5 \%$ and $221 \%$ for Elkharga, Eldakhla, Baris and balat districts, respectively. To achieve these improvements, the obtained optimal solutions proposed changing the farming plan of cropping pattern and modifying herd composition. The solution proposed that farmers should cultivate the whole cultivated area with alfalfa during winter season in Elkharga, Eldakhla, Baris and balat districts. While, in summer season farmers should cultivate the whole cultivated area with elephant grass in Elkharga, El dakhla and balat districts. On the contrary, farmers in Baris district should cultivate Darawa during summer season. The reasons for shifting towards these crops (alfalfa, elephant grass and darawa) may due to the highest GM generated among the other crops (Table, 2) in all districts.

On the other hand, concerning livestock enterprises, the optimal solution indicated that herd composition should include only five heads of goats in Elkharga district and one head of cattle in Baris district, while, in the other two districts the solution recommended no livestock enterprise. These changes in the herds composition could be due to lower variable costs required to keep five head of goats which are within the limits of the available cash flow with the smallholders (Tables, 1 and 2). These results 
are in agreement with findings obtained by Younis (1998) where, small ruminants could be more profitable than large ruminants in crop/livestock farming system in desert areas. From the economic point of view, the obtained optimal solutions are considered a feasible one, but practically not acceptable, where farmers have different goals other than just maximizing their farm GM to satisfy family consumption of different crops and livestock products and to avoid market risks.

To realize the expected farm GM, results of sensitivity analysis of the objective function revealed that GM generated per feddan of alfalfa should not be less than LE 5121, LE 7877, LE 4794 and LE 7709 for Elkharga, Eldakhla, Baris and balat districts, respectively. While in case of elephant gras s, GM per feddan should not be less than LE 3522, LE 8035 and LE 2636 for Elkharga, Eldakhla and Balat, respectively. On the other hand, in Baris district, GM generated from Drawa should not be less than LE 1380. Concerning the livestock enterprise sensitivity analysis revealed that GM rewarded from goat should not be less than LE 239 in Elkharga, and not less than LE 1371 for cattle rasied in Baris.

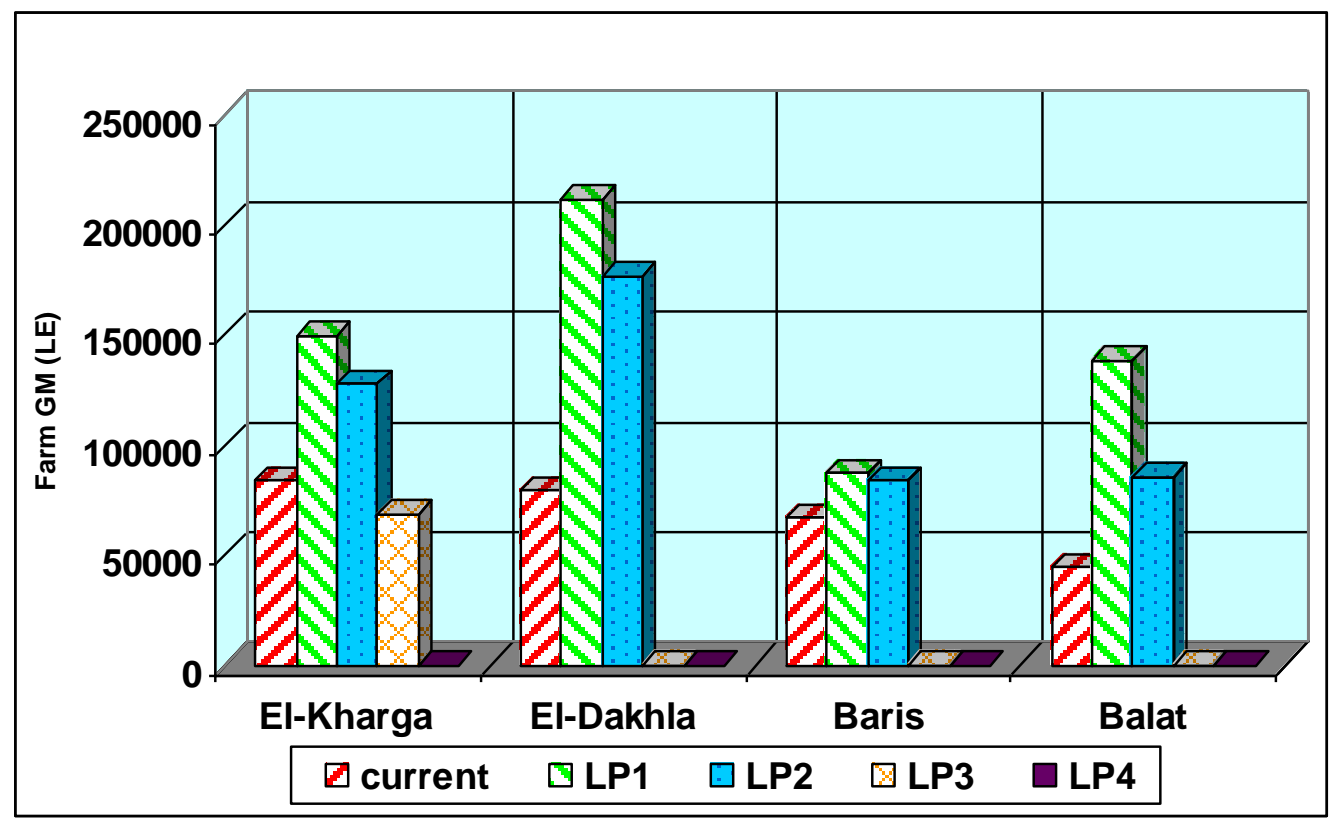

Fig. 1. Whole farm gross margin of the current situation and of the proposed farming plan scenarios for the studied districts.

\section{Modified herd composition scenario (LP2):}

The optimal solutions of LP2 scenario of Elkharga, Eldakhla, Baris and Balat districts are shown in Figure (1). The optimal solution offered significantly higher whole farm GM than that of the current situation by about $51.9 \%, 121.8 \%, 25.3 \%$ and $98.8 \%$, for the corresponding districts, respectively. The optimal solution proposed that farmers should change the current cropping pattern in all studied districts. In Elkharga district farmers should cultivate the whole farm area with alfalfa in winter and cultivate 4.3 feddan with elephant grass in summer. While, in Eldakhla, farmers should cultivate 7.7 feddan with alfalfa in winter and in summer cultivate 2.3 feddan with Elephant grass. In the same context, in Baris, farmers have to allocate the whole farm (4.45 feddan) with alfalfa in winter and 0.9 feddan with Elephant grass beside 3.5 feddan Darawa in summer season. While, in Balat farmers should cultivate 6.4 feddan with alfalfa in winter and in summer cultivate 10.7 feddan with elephant grass. Moreover, regarding livestock enterprise, the optimal solution recommended that, herd composition includes only one head of cattle, sheep and goat in each of the target districts.

Sensitivity analysis of the objective function showed that gross margin of alfalfa should not be less than LE 6329, LE7877, LE 4540 and LE 7708 for Elkharga, Eldakhla, Baris and Balat, respectively in winter and also, GM of elephant grass should not be less than LE 3522 and 8035 for Elkharga and Eldakhla, respectively in summer. Furthermore, the gross margin of darawa should not be less than LE 1922 in Baris district.

\section{Diversity of cultivated crops scenario (LP3):}

This scenario was mainly proposed to avoid environment uncertainty and to provide farmers with basic needed crops. The optimal solutions are shown in Figure (1). Result indicated that optimal solution resulted in an improvement in the expected farm GM over the actual situation by about $18 \%$ in Elkharga district. The sensitivity analysis of the objective function for in Elkharga district indicated that, the gross margin of goat should not be less than LE 239 per head. On the other hand, no feasible solution obtained for the other 3 districts of Eldakhla, Baris 
and Balat to maximize farm gross margin. These results could be due to these forced constrains that farmers must cultivate $1 / 4$ farm size by each crop in winter and 1/6 farm size by each crop in summer. These may lead to transfer money to cultivation, thus leaving less available cash resources to keep goat. Also, Bhatia and Gangwar (1981) found that, farmers have different type of attitude other than just maximizing their farm income. The obtained solutions support the findings of Abdulkadri and Ajibefun (1998) that, farmers could have objectives other than profit maximization like family consumption and diversification of crops to avert market risk.

\section{Real life scenario (LP4):}

Due to the assumed sets of constrains concerning the cropping pattern in addition to livestock activities. The obtained result of proposed farming plan (LP4) showed no feasible solutions for all studied districts. The obtained results support the findings of Ronald (1981) who reported that the type and quality of available production resources determine which enterprises can be considered in the whole farm plan and which can automatically be eliminated because the necessary resources are not available.

\section{Economical efficiency:}

Assessment of the economic efficiency of the current farming system was measured as the monetary value (GM) generated per unit of feddan (GM/feddan). Improvements of the economic efficiency of the proposed farming scenarios in comparison with the current situation are displayed in Figure (2). It is clearly observed that LP1 scenario (base run) achieved the highest GM/feddan, followed by LP2 scenario, in all the studied districts. The percentages of improvement are the same as those observed in the whole farm GM. From the food security point of view, practically this scenario did not satisfy the farmers goals, since results of optimal solution did not allocate any decision variable for the household food consumption.

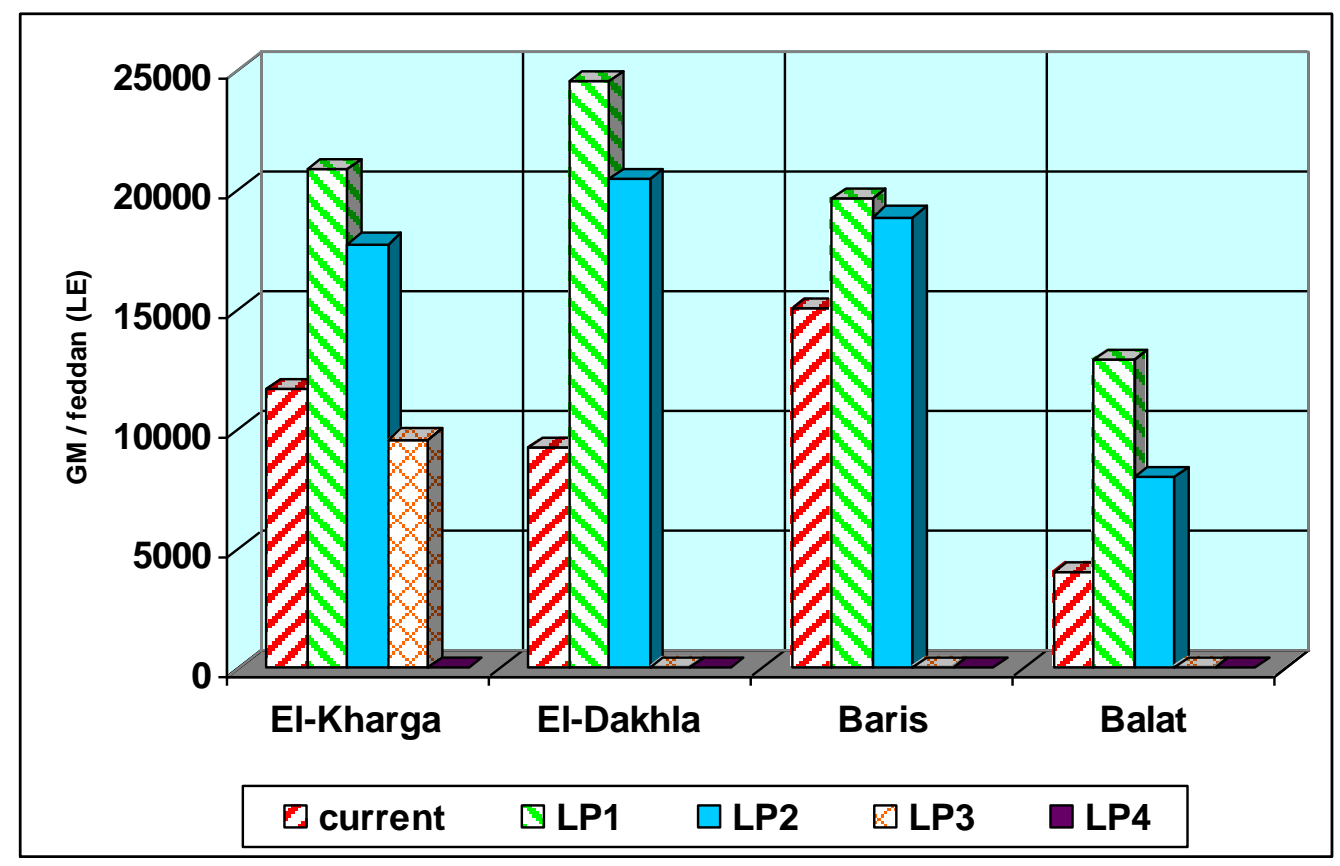

Fig. 2. Gross margin per feddan of the current situation and of the proposed farming plan scenarios for the studied districts.

\section{CONCLUSION}

The current study highlights the impact of allocation of the available production resources on the farm profitability. Comparison of results obtained by using conventional management practices of farm planning and linear programming model revealed that, optimal solutions derived from linear programming are more superior. It could be concluded that linear programming technique is a useful tool for farmers and decision makers. Such technique provides farmers and policy makers chance to select among alternatives farming plans scenarios that maximize farm income and support food security. The use of linear programming in resources allocation of crop/livestock farming system in the New Valley governorate might help to improve farm production in terms of maximizing farm profit and enhancing food security. Also, it is of great interest to notice that the response of different farming plans scenarios did not have the same impact on the farm GM for the target areas due to the availability of production resources, management practices and different constrains pertained in each area. The current study recommended that government policy should geared to financial support to smallholders to bridge the available cash flow constrain by 
establishing a credit lines for the smallholders in the studied districts.

\section{REFERENCES}

Abdulkadri, A. O. and I. A. Ajibefun, 1998. Developing alternative farm plants for cropping system decision making, Agriculture System, 4: 431-442.

Alary, V., A. Aboul-Naga, M. El Shafie, N. Abdelkrim, H. Hamdon and H. Metawi, 2016. Roles of small ruminants in rural livelihood improvement - Comparative analys is in Egypt.

Bhatia, H.C. and A.C. Gangwar, 1981. Optimum combination of crops and livestock enterprises on small farms in Karnal district. The Indian Journal of Dairy Science 34: 60-66.

CAPMS, 2015. Central Agency for Public Mobilization and Statistics. Statistical year book, Cairo.

EEAA \& EMU, 2008. State Ministry of Environment and New Vally Governorate. Report for 20072008: Environmental Action Plan, New Valley Governorate.

FAO, 2009. The state of food and agriculture. Rome 2009. Italy. Pp 180.

FAOSTAT, 2014. Statistical Database. Food and Agriculture Organization. (www.http://fao.org/default.aspx).

GAMS, 2000. General Algebra Modeling System Software, Version. 2.5, GAMS Development
Corporation, 1217 Potomac St, N W Washington, DC 20007, USA.

Majeke, f., M. Judith, M. Jonathan and S. Munashe, 2013. Modeling a small farm livelihood system using linear programming in Bindura, Zimbabw.

Mona Mohammady, I., M.N.M. Abd El-Ati, H.Hamdon and Doaa A. Abd El-Salam, 2019. Characterization of crop/livestock farming system in New Valley of Egypt using system approach. Egyptian J. Anim. Prod., 55 (3): 163-169

Notenbaert A., M., Herrero R.,Kruska L., You S., Wood P., Thornton A. Omolo 2009. Classifying livestock production systems for targeting agricultural research and development in a rapidly changing world. Discussion Paper No 19 .Livestock Research Institute International.

Rickert, K. G. and G. M. Mckeon, 1991. Modelling as an aid to systems evaluation. In: V. R. Squires and P. G. Tow (Ed.) Dry Farming, A System Approach, An Analysis of Dryland Agriculture in Australlia. Pp 209 - 221. Sydney University Press, Australlia.

Ronald, D. K., 1981. Farm Management. McGrawHill Book Company, New York.

SAS, 2004. Statistical Analysis System, SAS User's Guide , SAS Institute Inc., Cary, NC.

Younis, A. A., 1998. Small ruminant production systems in Egypt. Egyptian J. Anim. Prod., Suppl. Is sue, 35: 128-144.

\footnotetext{
تطبيق اسلوب البرمجة الخطية فى نمذجة النظام الزراعى النباتى/ الحيوانى الحالى فى محافظة الوادى الجديد فى مصر محمد نصرت محمود عبد العاطى'، منى محمدى ابر اهيم ، حاتم عبد القار محمد حمدونّ، دعاء عاطف عبد السلامّ 